JUDIT SZÉPE (Strasbourg-Budapest),

KÁROLY GERSTNER, TAMÁS SZENDE (Budapest)

\title{
ON DEFECTIVE VERBS AND MOOD MARKING IN HUNGARIAN*
}

\begin{abstract}
In this paper irregular inflection of Hungarian defective verb forms of the type csuklik 'hiccough', hámlik 'peel', etc. is discussed. The final shape of the phonological representation of irregular forms in question tends to be subject to rules of segmental sequence organisation, i.e. optimality requirements of the syllable structure. However, parallel normative variants like hajolna and hajlana 'would bend' with similar optimality values in view of their syllabic structure show that their undoubtedly systematic distribution should be accounted for along the lines of criteria beyond morphophonology. Our analysis suggests that the choice between the members of the pairs lies on the argument structure of the verb, that is to say, whether the argument is an agent or a patient, cf. hajolsz and hajlasz 'bend [Indicative, 2sg]' with the subject agent and patient, respectively.
\end{abstract}

Keywords: Hungarian, phonology, morphosyntax, Systemzwang (pattern congruence), semantics.

1. In this paper, we will raise the issue of what it is exactly that determines the inflected forms of Hungarian defective verbs of the type csuklik 'hiccough', kotlik 'brood', hámlik 'peel'. We start with three hypotheses. 1.1. Anomalies in the suffixation of certain lexical items are not independent of the semantic-functional content of those lexical items. Note in this respect that (a) p e r d e f i n i t i o n e m, words (word forms) have independent denotata; (b) however, independent denotata are not necessarily individual denotata, that is, 'things'; (c) if a denotatum is not individual, the corresponding word will tend to have an irregular morphological paradigm. For instance, definite articles often do not have plural forms. In the inflectional paradigms of pronouns and "pro-adverbs" that historically go back to deictic elements, suppletive stem alternations are commonly encountered, cf. ó 'he/she' vs. vele 'with him/her'; én 'I' vs. engem 'me (acc.)', etc. Auxiliaries tend to be defective, thus $s z o k-i k$ 'do as a habit', when used as an auxil-

\footnotetext{
* We have received expert help both in developing the basic ideas of this paper and in matters of detail from Ildikó Bodnár, László Elekfi, Péter Siptár, and György Szépe. Our results are in part theirs; any errors that might remain are exclusively ours.
} 
iary, has past tense forms only (szok-t-am 'I usually do' [literally: 'I used to']), and $f \circ g$ 'will' has no participial or past-tense forms in present-day Hungarian. Similarly, words that start out as adjectives may receive verbal inflections by paradigm shift, provided that their semantic role is to add some modal meaning to the verb phrase of the sentence (e.g., szabad 'free' vs. szabad-na [megkérdeznem] 'might I [ask]' [literally: 'free-COND'], szabadjon [megjegyeznem 'let me [note]' [literally: 'free-IMP']), and so on.

1.2. The final shape of the phonological representation of irregular forms tends to be subject to rules of segmental sequence organization. That is, optimality requirements of syllable structure, at least partially languagespecific as they are, play a crucial role in what come to be lexically specified surface variants. In particular, those variants are determined by what types of syllable coda are phonotactically permitted in individual inflected forms of the given stem.

1.3. We will necessarily come across cases in which functional requirements of inflected forms clash with phonotactic regularities (as we will see below, this is the case with ?csukoljon 'let him hiccough', for instance). In such cases, the organizing principle that prevails is essentially extraphonological, i.e., one that reflects the primacy of function: a principle that used to be technically called Systemzwang 'pattern congruence', or (later) 'analogy'.

In this paper, we try to demonstrate that the above hypotheses are sound and can be applied as explanatory principles in the analysis of the group of verbs concerned.

2. A couple of representative examples will suffice to show that the issue at hand has not received satisfactory morphophonological treatment in the recent literature, or so it seems in retrospect.

2.1. Szépe (1969) does not devote a separate section to the group of verbs we are interested in here. We can at best reconstruct the way their description would have run in his generative theory of Hungarian phonology. For simplicity, let us concentrate on alternative conditional forms of hajlik 'bend', hajolnának vs. hajlanának 'they would bend'. Note in passing that this optionality of parallel forms cannot simply be ascribed to the fact that the verb is of the $i k$-class today (cf. Siptár, Törkenczy $2000: 36$ ): its affiliation is a matter of historical change itself. Its obsolete imperative hajoljék 'let it bend' presupposes an $i k$-class stem, whereas the alternative form hajoljon 'let it bend' suggests a non-ik-class stem (cf. also romoljék/romoljon 'let it deteriorate', bomoljék/bomoljon 'let it disintegrate'). It is clear that we have two alternative forms here that (following Szépe 1969 : 435) can be represented in a generalized form as in (1):

$$
\text { hajla- }{ }^{\text {hajol- }}[n .] n a k
$$

The emboldened vowels $o$ and $a$ (represented in IPA symbols as [o] and $[\mathrm{A}]$ in what follows) are both connectives, even though morphologically they belong to two different levels. Their categorial difference is shown, among other things, by the fact that the default value of linking vowels, for verb stems of the shape ...CVC-, is either zero or a mid vowel. Yet in hajla-, we find [A]. Why is that? We have no explanation that would be satisfactory in all respects (though Rebrus, Polgárdi (1997) offer an inter- 
esting suggestion). György Szépe (personal communication) assumes the following points: (i) the [A] occurs after a consonant cluster (this is a fact, but does not explain the quality of the vowel); (ii) with recategorization into the $i k$-class ( ${ }^{*} h a j o l \mathrm{~V}$ - $\rightarrow$ hajlik), the structure of the morpheme undergoes a change: morphological generation "takes precedence" over the routine operation of normal sequence organization (that is, an abstract IK marker has to be assumed), from which it follows that "concrete pre-ik" stems behave differently in selecting a linking vowel, bringing about a "marked" state of affairs. Perhaps in a way that they anticipate the [A] of the 3 pl person-number suffix -nak. Be that as it may, in a restricted Szépestyle description, both stem alternants show the effect of having undergone rule (2):

(2) $[-$ segment $] \rightarrow[+$ segment $] /\left\{\begin{array}{c}{[- \text { voc }]} \\ {[+ \text { cons }]} \\ \ldots\end{array}\right\}-\left\{\begin{array}{c}{[- \text { voc }]} \\ {[+ \text { cons }]} \\ \ldots\end{array}\right\} / /$ Conditional

However, (2) has to be made more specific with respect to hajlik, on several counts. First of all, in the left-hand environment, the specification [+ cons] has to be omitted, in order to cover $j$, in the case of the alternant hajol- (whereas for hajla-, [+cons] of course remains).

Second: we have to determine which alternant is the primary one. However, this is simple: the alternant hajla- can be more easily derived form the phonologically more full-fledged hajol- than the other way around (for the details, see below).

Next, we have to provide a rule for the feature values of the "[+ segment]" output of (2), an easy task again with respect to hajol- (cf. Szépe 1969 : 436):

(3)

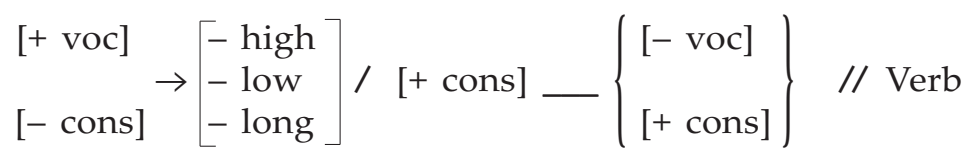

On the other hand, the $a$ in hajla- requires a different output specification:

(4) $\left[\begin{array}{l}+ \text { low } \\ - \text { long }\end{array}\right]$

The two versions of the rule obviously apply in complementary environments (at the surface, we get either hajol- or hajla-). However, previously or underlyingly, both vowels had to/have to occur simultaneously, even if at different points of the sequence. That conclusion is also corroborated by historical facts: "older verbs [those attested prior to the second half of the 18th century] had a vowel-final stem alternant, too. And that alternant occurred before other suffixes (-nak/-nek, -m, etc.) as well” (Károly 1957 : 280). Given the Proto-Hungarian syllable structure CVCV, a hypothetic *hajola(+suffix) form (e.g. *hajolana 'it would bend') could underlie both hajol(+suffix), e.g. hajolna, and hajla(+suffix), e.g. hajlana, with Horger's law being applied to two different syllables (Horger 1911). The historical tendency of Two-Open-Syllable Shortening, first identified and described in detail by Antal Horger as early as in 1911, was a very much 
productive process in Old-Hungarian active mainly between the 10th century and the middle of the 14th century bringing about new paradigms both in the declension and the conjugation systems by syncopation, cf. [sErElemV] 'love' $\rightarrow$ [sErElmEt] 'love+ACC' or [urusagV] 'land' $\rightarrow$ [orsa:g] 'land'. If that "law" applies to delete the third vowel of *hajolana, we derive hajolna, if it applies to delete the second vowel, the output is hajlana. That is, as György Szépe would put it, there is a sequence (linear) constraint here. Note that the $[a]$ in hajla- occurs as an obligatory constituent stem finally, e.g. before a conditional suffix, compare hajlanának 'they would bend' with játszanának 'they would play', váltanának 'they would switch'. Thus, hajl-, hajol-, hajla- are in complementary distribution, at least at the level of occurrences, constituting combinatorily conditioned alternants as inputs to further suffixation, just like in the case of all C1C2-final verb stems, cf. játszik 'play', vált 'switch', etc. It is in this sense that - via operational simplification - we may take hajla- to be one of the stem alternants of hajlik 'bend' in present-day Hungarian.

So far so good; the only remaining task would be to formulate the exact conditions of both synchronic rules involved. Szépe's rules often include syntactic conditions, some of them referring to mood (as in (2) above, or in Szépe 1969 : 443). However, such conditions do not come into play here. As we will see, the solution has to be found elsewhere.

2.2. Siptár (1995) does not discuss this problem at all, as a consequence of his theoretical framework and attitude. In principle, the distribution of stem alternants would be explained - if at all - in terms of lexical rules. The only point where we might find a path towards a solution would be the rule-governed nature of the selection of both stem and suffix allomorphs. However, in this respect, we find the following thesis: "The distribution of the allomorphs of such stems [ $l$ "' 'shoot', $f$ "' 'be cooked', szö 'weave', ró 'scribble', etc. - examples added] can be predicted in terms of syllable structure. These stems surface as consonant-final if and only if that final consonant can be syllabified as the onset of the next syllable, that is, whenever they are followed by a vowel-initial suffix. However, if such syllabification is impossible, that is, word finally (where there is no subsequent syllable) or before a consonant-initial suffix (where the next onset slot is already occupied), the underlying stem-final consonant merges with the preceding vowel, making it long” (Siptár 1995 : 63). This may well be true in itself - but such a rule could not account for an alternation like that between hajol- and hajla-. In a slightly different perspective, we could consider the latter case to be that of vowel epenthesis in stems ending in $\mathrm{C}+l$ or $\mathrm{C}+r$, wherever a syllable would otherwise end in a sonority reversal or a sonority plateau (cf. Dressler, Siptár 1989). This would cover the case of hajol-, too. The phenomenon is indeed rather widespread in Hungarian; yet in itself it does not account for the stem alternation at hand. This is because the phonotactically unmotivated schizophrenia of vowel epenthesis, that is, hajl- $\rightarrow$ hajol- or hajla-, both occurring before consonant-initial suffixes, remains unexplained.

The final solution, in Siptár's framework, can only be that the difference is lexically encoded, and the phonological rules that the two forms undergo are distinct and mutually independent. However, the two stem forms are alternants of one another, after all. So much so that a virtual 
imperative of the stem alternant hajla- is based on that of the alternant hajol- (cf. *hajlaj-, *hajlj- vs. hajolj-).

2.3. Another essentially syllable structure based approach is that of Szigetvári (2001). He exemplifies the phenomenon of syncope, fairly consistently occurring in Hungarian as well as in other languages, by morphologicallyinduced alternations. As parallel sets of examples like mozog/mozogjon/ mozoghat 'he moves/let him move/he can move' mozgat/mozgott/mozgó 'he moves sg/he moved/moving' suggest, "the non-occurrence of the vowel [between $z$ and $g$ ] is a function of whether the following consonant is or is not followed by a pronounced vowel. An empty $\mathrm{V}$ slot that precedes a silent $\mathrm{V}$ slot $[=$ a vocalic position that is lexically empty and is not filled in by some default value in actual pronunciation, either - definition added] may not remain silent itself" (Szigetvári 2001 : 52). In essence, this accords with Horger's law (cf. Horger 1911), albeit in a reverse formulation: in Horger's view, the underlying form is the fuller one, containing the vowel (cf. szerelem 'love' $\rightarrow$ szerelmet 'love-ACC'). It can immediately be seen that suffixed forms of both hajol- and hajla-fulfil the requirements of syncope. Thus, we have not made much progress in this case, either, given that no explanation has been offered as to why the empty $\mathrm{V}$ slot comes to be pronounced where it is.

2.4. Rebrus (2000) approaches a larger set of phenomena (that includes our present problem) from the direction of suffixes, that is, from a consistently morphological point of view. In his analysis, there are quasi-analytical suffixes that "may form two types of forms with epenthetic stems: one with, and one without the vowel that alternates with zero". On the other hand, analytical suffixes "never induce loss of the alternating vowel" (Rebrus 2000 : 846). As we will see, the existence of two possible forms (or the choice between them) does not depend on the suffix, on whether it is quasi-analytical or otherwise. The regularity of stem alternants resides in the stem itself, and has much deeper roots than the combination of stems and suffixes. It is also instructive at this point to remind the reader of Lotz's (1960/1972) approach, radically different as it was both in its theoretical premises and its practical solutions. He based his classification of the alternations involved in imperatives on the "premorphemic alternations" of the verb stems. The various stem alternants were then concatenated with the relevant alternants of the mood marker (of which the "basic alternant is $-j$ ", showing the minimum degree of phonetic motivation). The selection of the appropriate premorphemic alternant and the appropriate explicit imperative morpheme was done mainly by phonemic selection, either regressively or progressively; in a substantial subset of the cases, however, "a reciprocal dual selection" was shown to take place. In Lotz's own words: "Here the premorpheme determines the selection among the imperative morpheme alternants, and the imperative morpheme selects the alternant corresponding in friction or palatality among the alternants of the premorpheme" (Lotz 1960/1972 : 45), cf. metssz/mess 'cut-IMP', bocsáss 'let go-IMP', etc. The various mood-marked forms of the group of verbs we have studied have convinced us, pace Lotz, that what matters is the stem, but we wish to point out once more: the relevant choices are determined at a deeper level than that of either the underlying or the surface phonology or morphology of the stem alternations. 
3. Let us now turn to a "partially complete" taxonomy of the specific group of verbs concerned here. According to Károly (1957 : 275-281), approximately seventy verbs belong here. His sources (dictionaries of Standard Hungarian and of various local dialects) are often in disagreement about which suffixed forms of which of these verbs are acceptable and which ones are dubious or downright wrong. The evaluative application of the notion of "acceptability" is, at any rate, inaccurate with respect to certain word forms. Dictionaries that include acceptability labels attached to some of the forms they include mainly do that on the basis of the frequency of occurrence of the various alternative forms. Elekfi (1988: 60), for instance, writes this: "along with standard romlasz 'you deteriorate', the alternative romolsz is much rarer". Note, however, that the members of such pairs of forms may belong to distinct (semantic) categories. For instance, the relationship between hajolsz 'you bow' and hajlasz 'you bend' is different from that between ?pirosolsz and its "primarily correct variety" piroslasz 'you redden' (cf. Elekfi 1988:60-61). The subjects of both members of the latter pair have the same semantic role, whereas in the case of hajolsz vs. hajlasz an action and an event are contrasted, and their subjects are an agent and a patient, respectively, that is, not the same (see below). Even with this important distinction in mind, we have to reckon with variability or vacillation in some individual cases where it is the task of sociolinguistic research to come up with reliable usage labels. On the other hand, we will make definite statements concerning general, shared properties of these verbs as a group.

3.1. The group consists of $i k$-verbs whose inflectional paradigms are defective. On the one hand, their stem alternant that directly precedes - $i k$ cannot cooccur with the imperative morpheme, e.g., *csukljon 'let him hiccough', *kotljon 'let him brood', *hámljon 'let him be peeling'. This is because they end in a consonant cluster (before $-i k$ ) that is very rare in Hungarian as a syllable coda not divided by a morpheme boundary (C1C2\#) (fájl 'file'; ajánl 'recommend'; görl 'chorus girl'; rajz 'drawing', felajz 'excite', spájz 'larder', csuszpájz 'vegetable dish'; nemz 'beget'; borz 'badger', torz 'malformed', torzonborz 'shaggy', perverz 'perverted', traverz 'girder'), and never occurs as a word-final cluster divided by a morpheme boundary (C1\#C2\#\#) (cf. Elekfi 1992 : 15-30, 84-86; Törkenczy 1994 : 300-301). Such clusters are the following: [dl, gl, hl, jl, $k l, m l, n l, r l, s ̌ l, t l, h l, z l, s l, b z, g z, j z, k z, l z, m z$, $p z, r z]$. Except for $[j l, r l, m z, j z, r z]$, these syllable codas violate the Sonority Sequencing Principle (Törkenczy 1994 : 276, 314).

Let us first look at some irregular occurrences.

(a) There are six consonant clusters that do exist word finally but the verbs ending in them nevertheless lack imperative forms: these are [ps], cf. alapszik 'be based on' - *alapsszon; [rs], cf. ismerszik 'be recognizable by' *ismersszen; [ks], cf. dicsekszik 'boast' - *dicseksszen; [ls], cf. alszik 'sleep'*alsszon; [ńs], cf. megkeményszik 'become stiff' - *megkeménysszen; [nz], cf. burjánzik 'grow apace' - *burjánzzon. These stems have alternants, as a rule, that are distinct in their second morpheme component such as dicsek\#szik dicsek\#edik; alap\#szik alap\#ul, or megkemény\#szik megkemény\#edik. In the second memberss of this pairs the derivational suffix with a VC structure enables them to have a regular imperative as well as further affixed forms, viz. dicsekedjen, alapuljon, megkeményedjen. The 
imperative in the first type of alternants will coincide with that of the synonymous stem alternant (with the exception of ismerszik having no stem alternant, so its imperative will be built up of - $h A t$ 'can' + participle in the periphrasis legyen felismerhetó 'be it recognizable'.

(b) The word final clusters $[n g, l l, d z]$ only occur in Hungarian undivided by a morpheme boundary. In - $i k$ verbs, $[n g]$ occurs likewise undivided, cf. fingik 'fart' - fingjon, whereas $[l l]$ and $[d z]$, a geminate and a (probable) cluster, respectively (cf. Siptár 1994 : 185-196; Törkenczy 1994 : 327-330; respectively, Siptár 1995 : 34-36; Törkenczy 1994 : 207-210) perhaps behave as if they were not clusters at all, since - although the playful versions rinogjon 'let it sway', finogjon 'let him fart' can be formed after the existing inogjon 'let it wobble' - there are no models for forms like *sárgáloljon 'let it be yellow', *borsódozzon 'let [one's flesh] crawl' (but cf. sarjadzik 'to bud' - sarjadozzon 'let it bud' with a short vowel in the stem).

(c) There are two pre-ik clusters that never occur in Hungarian as word final codas divided by a morpheme boundary (due to phonological rules that eliminate them): $[g s]$ and $[t s]$. Both clusters occur in verbs that do have imperative forms. But these forms are not based on the stem alternant including [gs], cf. haragszik 'be angry' - haragudjon, nyugszik 'be at rest' - nyugodjon (see also aparallel cases like merevszik 'become stiff' merevedjen). It is only verbs containing pre-ik [ts] whose imperatives are regular and non-suppletive: hallatszik 'be audible' - hallatsszon, tetszik 'be pleasant' - tetsszen, látszik 'be visible' - látsszon. We will ignore these irregular cases in what follows.

On the other hand, speakers' intuition bristles up against their (noncanonical) imperative forms modelled after cases like rablok 'I rob' raboljon 'let him rob', that is, csuklom 'I hiccough' - ?csukoljon 'let him hiccough', hámlok 'I am peeling' - ?hámoljon 'let him be peeling'. This in spite of the fact that such forms would be phonotactically permissible, cf. zsákoljon 'let him dunk', rámoljon 'let him pack'.

3.2. The verbs we will analyse here (collected from SzmSz and ÉKsz.) are all unaccusatives (traditionally also known as middle voice verbs), that is, they are intransitive verbs whose subject is in a state or undergoes an event expressed by the verb or whose subject is not identical with the agent of the action expressed by the verb; the action that the subject undergoes is carried out by an external agent. Their shared peculiarity is that their imperative forms express a wish rather than a command (Lengyel 2000 : 85). Comparing the paradigms of intransitive verbs lacking an imperative form with their transitive counterparts (even if there is no semantic relationship between them - signalled by shading in Table 1 below), we find the following forms in the third person singular present indicative, conditional, and imperative (we ignore imperative forms of the obsolete $i k$-paradigm since that difference is irrelevant for our present purposes as they do not affect the phonotactic structure of the stems before the mood suffix).

Table 1 includes the imperative of intransitive verbs under cond.1 and those of transitives under cond.2. It seems to be unavoidable to list both cond.1 and cond.2 for the two groups of stems since their distribution is not exceptionless. For example, there occur cond.1 forms among transitive stems using otherwise regular cond.2, which turn out to be though "questionable" but not ill-formed, cf. kiötöl - (?)kiötlene. On the other hand, as 
for intransitives, there are not only cond.2 forms judged basicly ill-formed cases with the index "questionable" (ötlik - (?)ötölne) or even qualified as well-formed (vérzik - vérezne), but also some instances of their regular cond.1 forms show up as questionable or - according to some scholars' opinion - ill-formed (érzik - érzene; vérzik - vérzene). It is worth mentioning at this point that, as for érzik, it does not have either wellformed cond.1 or well-formed cond. 2 as some experts suggest.

Note that torlik 'pile up' does not occur in the revised edition of ÉKsz. (Pusztai 2003), while verbs marked by † (here: párlik 'be humid' which occurs in neither edition of ÉKsz.; it can be found, however, in SzmSz 186) did not qualify as active members of the synchronic Hungarian word stock in 1972, either. However, this is irrelevant with respect to their morphophonological behavior.

With respect to the acceptability of the forms in the table we have primarily relied on our own observations whose results were then compared to the corresponding labels in MRSz (Elekfi 1994) and Grétsy (1985). Deviations from acceptability judgements in those two sources will be marked as follows. MRSz lists forms marked by! here as forms with dubious acceptability, and those marked !! here as unacceptable. Those marked by • (in Table 2) are listed as well-formed by Grétsy (1985).

In the case of the intransitive members of these pairs of verbs, only one of the two potential conditionals is systematically well-formed: the one in which no vowel is inserted into the consonant cluster preceding the $-i k$, as in porlik - porlana, whereas in the case of the corresponding transitive verbs, the well-formed version is the one involving an (re)inserted vowel: porol - porolna. That is, the former uses the stem porl-, and the latter uses the stem porol-, throughout their paradigms. In the imperative, the $-j$ mood marker can only be added in a phonotactically regular manner to the stem type exemplified by porol: poroljon. A form like *porljon is phonotactically irregular, containing a consonant cluster that is impossible in Hungarian verb forms. On the other hand, if that irregular cluster were to be repaired by vowel insertion, the result would be homophonous with transitive poroljon. We assume that ?érzene 'would be felt', the regular (but practically unacceptable) conditional form of érzik, has been replaced by érzôdne (the conditional of another - though derivationally related - verb: érzödik 'is felt', containing the explicit passive/reflexive suffix -ö $d-$ ) because it is homophonous with a potential compound noun ér-zene 'the music of the veins' (which could in fact be not more than an innovative metaphor for cardiologists). Another reason for that substitution is that the -ik of érzik - as contrasted to the non-ik, active érez 'feel' - does not convey any passive/middle voice meaning any more. That is why its inflectional paradigm has become defective and why it has been replaced by the explicit form érzödik whose inflectional paradigm does not involve any phonotactic anomaly. In the case of vérzik 'bleed', an analogous *vérzódne has not proved to be appropriate to replace ?vérzene 'would bleed' (that also has a virtual homonymous compound 'blood music'), making the corresponding transitive form, vérezne 'would stain with blood', deputize in the role of 'would bleed', too. With the licencing of the stem alternant involving the vowel $e$ in the intransitive paradigm, the intransitive use ('let it bleed') of the transitive imperative vérezzen 'let him stain sg with blood' has also 
Table 1

\begin{tabular}{|c|c|c|c|c|c|c|c|}
\hline $\begin{array}{l}\text { intransitive, } \\
\text { indicative }\end{array}$ & $\begin{array}{l}\text { intransitive, } \\
\text { cond.1 }\end{array}$ & $\begin{array}{l}\text { intransitive, } \\
\text { cond.2 }\end{array}$ & intransitive, & \begin{tabular}{|l|} 
transitive, \\
indicative
\end{tabular} & $\begin{array}{l}\text { transitive, } \\
\text { cond.1 }\end{array}$ & $\begin{array}{l}\text { transitive, } \\
\text { cond.2 }\end{array}$ & $\begin{array}{l}\text { transitive, } \\
\text { imperative }\end{array}$ \\
\hline \begin{tabular}{|l} 
porlik \\
'powder \\
away'
\end{tabular} & porlana & ${ }^{*}$ porolna & *poroljon & $\begin{array}{l}\text { porol } \\
\text { '(beat } \\
\text { the) dust } \\
\text { (out of)' }\end{array}$ & *porlana & porolna & poroljon \\
\hline torlik & torlana & *torolna & *toroljon & torol & *torlana & torolna & toroljon \\
\hline párlik† & párlana & * párolna & *pároljon & $\begin{array}{l}\text { párol } \\
\text { 'stew, } \\
\text { distil' }\end{array}$ & *párlana & párolna & pároljon \\
\hline $\begin{array}{l}\text { özönlik } \\
\text { 'flock } \\
\text { (to a place)' }\end{array}$ & özönlene & *özönölne & özönöljön & $\begin{array}{l}\text { elözönöl } \\
\text { 'swarm } \\
\text { into' }\end{array}$ & *elözönlene & elözönölne & elözönöljön \\
\hline $\begin{array}{l}\text { hírlik } \\
\text { 'is } \\
\text { rumoured' }\end{array}$ & hírlene & *hírelne & *híreljen & $\begin{array}{l}\text { elhirel } \\
\text { 'spread } \\
\text { the news } \\
\text { of' }\end{array}$ & *elhírlene & elhírelne & híreljen \\
\hline $\begin{array}{l}\text { ötlik } \\
\text { 'occur } \\
\text { (to sy)' }\end{array}$ & ötlene & ?ötölne & ?ötöljön & $\begin{array}{l}\text { kiötöl } \\
\text { 'figure } \\
\text { out' }\end{array}$ & (?)kiötlene & kiötölne & kiötöljön \\
\hline $\begin{array}{l}\text { porzik } \\
\text { 'be covered } \\
\text { in dust' }\end{array}$ & porzana & *porozna & ${ }^{*}$ porozzon & $\begin{array}{l}\text { poroz } \\
\text { 'raise } \\
\text { dust' }\end{array}$ & ${ }^{*}$ porzana & porozna & porozzon \\
\hline $\begin{array}{l}\text { érzik } \\
\text { 'be felt' }\end{array}$ & érzene !! & *érezne !! & ?érezzen !! & $\begin{array}{l}\text { érez } \\
\text { 'feel' }\end{array}$ & *érzene & érezne & érezzen \\
\hline $\begin{array}{l}\text { vérzik } \\
\text { 'bleed' }\end{array}$ & ?vérzene !! & vérezne & vére & $\begin{array}{l}\text { vérez } \\
\text { 'stain } \\
\text { with } \\
\text { blood' }\end{array}$ & *vérzene & vérezne & vérezzen \\
\hline $\begin{array}{l}\text { sugárzik } \\
\text { 'beam' }\end{array}$ & sugárzana & *sugározna & *sugározzon & $\begin{array}{l}\text { sugároz } \\
\text { 'broad- } \\
\text { cast' }\end{array}$ & *sugárzana & sugározna & sugározzon \\
\hline $\begin{array}{l}\text { nyálzik } \\
\text { 'slaver' }\end{array}$ & nyálzana & *nyálazna & *nyálazzon & $\begin{array}{l}\text { myálaz } \\
\text { 'lick' }\end{array}$ & *nyálzana & nyálazna & nyálazzon \\
\hline fogzik, & fogzana & ${ }^{*}$ fogazna & ${ }^{*} f \circ g$ & $\begin{array}{l}\text { fogaz } \\
\text { 'indent' }\end{array}$ & ${ }^{*}$ fogzana & fogazna & fogazzon \\
\hline $\begin{array}{l}\text { habzik } \\
\text { 'foam' }\end{array}$ & habzana & *habozna & *habozzon & $\begin{array}{l}\text { haboz } \dagger^{1} \\
\text { 'cover } \\
\text { with } \\
\text { foam' }\end{array}$ & *habzana & habozna & habozzon \\
\hline $\begin{array}{l}\text { szaglik } \\
\text { 'stink' }\end{array}$ & szaglana & ${ }^{*}$ szagolna & ${ }^{*}$ szagoljon & $\begin{array}{l}\text { szagol } \\
\text { 'take } \\
\text { a smell } \\
\text { of' }\end{array}$ & ${ }^{*}$ szaglana & szagolna & szagoljon \\
\hline $\begin{array}{l}\text { vedlik } \\
\text { 'slough, }\end{array}$ & vedlene & *vedelne & *vedeljen & $\begin{array}{l}\text { vedel } \\
\text { 'drink } \\
\text { a lot' }\end{array}$ & *vedlene & vedelne & vedeljen \\
\hline $\begin{array}{l}\text { fejlik } \\
\text { 'get } \\
\text { unstitched' }\end{array}$ & fejlene & ${ }^{*}$ fejelne & *fejeljen & $\begin{array}{l}\text { fejel } \\
\text { 'head } \\
\text { (the ball)' }\end{array}$ & *fejlene & fejelne & fejeljen \\
\hline
\end{tabular}

$\overline{1}$ haboz 'cover with foam', cf. TESz. $2: 7$. 
become viable. (On the other hand, the unacceptability of intransitive *ére zne 'would be felt' makes the intransitive use of ??érezzen 'let it be felt' at least doubtful.) The form kiötlene 'would figure out' of transitive kiötöl, a conditional form that a number of subjects accept as well-formed, is based on paradigm blend: the verb has the recent variant kiötlik whose paradigm necessarily involves kiötlene (rather than kiötölne). Speakers' uncertainty in evaluating conditional ötölne and imperative ötöljön (from ötlik 'occur to somebody') is presumably due to the same factors.

3.3. Verbs that do not have a transitive counterpart (Table 2) also behave regularly as described so far. Their inflectional paradigms involve a stem alternant without a (re)inserted vowel. This regularity would be violated by their imperative forms - more or less clearly rejected by spekers' intuition - that would invariably be based on a stem alternant with an inserted

Table 2

\begin{tabular}{|c|c|c|c|}
\hline intransitive, indicative & $\begin{array}{l}\text { intransitive, } \\
\text { cond.1 }\end{array}$ & $\begin{array}{l}\text { intransitive, } \\
\text { cond.2 }\end{array}$ & $\begin{array}{l}\text { intransitive, } \\
\text { imperative }\end{array}$ \\
\hline vonaglik 'writhe' & vonaglana & *vonagolna & ?vonagoljon • \\
\hline robajlik 'make a din' & robajlana & *robajolna & *robajoljon \\
\hline rejlik 'be hidden' & rejlene & *rejelne & *rejeljen \\
\hline sejlik 'make itself felt' & sejlene & *sejelne & *sejeljen \\
\hline sikamlik 'be slippery' & sikamlana & *sikamolna & ?sikamoljon \\
\hline villámlik 'it is lightning' & villámlana & *villámolna & ?villámoljon • \\
\hline hámlik 'be peeling' & hámlana & *hámolna & ?hámoljon \\
\hline gyülemlik 'be gathering' & gyülemlene & $*_{\text {gyülemelne }}$ & ?gyülemeljen \\
\hline meghasonlik 'be at variance with' & meghasonlana & *meghasonolna & ?meghasonoljon \\
\hline fehérlik 'look white' & fehérlene & ${ }^{*}$ fehérelne & *fehéreljen! \\
\hline magaslik 'be towering' & magaslana & *magasolna & *magasoljon ${ }^{2} !$ \\
\hline hanyatlik 'be in decay' & hanyatlana & *hanyatolna & *hanyatoljon! \\
\hline sötétlik 'look dark' & sötétlene & *sötételne & *sötételjen !・ \\
\hline fénylik 'gleam' & fénylene & *fényelne & *fémyeljen !• \\
\hline símylik 'suffer' & símylene & *símyelne & *símyeljen \\
\hline viszomylik 'relate to' & viszomylana & *viszonyolna! & *viszonyoljon \\
\hline izlik 'taste good' & izlene & *izelne & *izeljen! \\
\hline büzlik 'stink' & büzlene & *büzölne & *büzöljön !•• \\
\hline csuklik 'hiccough' & csuklana & *csukolna & ?csukoljon • \\
\hline foszlik 'fray' & foszlana & ${ }^{*}$ foszolna & ?foszoljon! \\
\hline etc. & & & \\
\hline
\end{tabular}

2 While the occurrence of forms like fehéreljen 'let it look white', sötételjen 'let it look dark' in older dictionaries is mentioned by Károly (1957 : 278), he writes about magasoljon 'let it tower high' (well-formed according to MRSz): "magaslik 'be towering', on the other hand, has no such form". In the varieties of Hungarian in that viszonyul is the stem alternant of viszonylik the verb in question belongs to Table 3 instead of Table 2 (see below). 
vowel, corresponding to the potential transitive verb that does not exist in these cases. Recall that, for porlik 'powder away', intransitive poroljon is impossible, among other things, because it coincides with the regular transitive imperative. On the contrary, for csuklik 'hiccough' (and similar items), no transitive imperative is available (since they have no transitive counterpart to begin with), therefore the formation of $?^{*}$ csukoljon etc. is not blocked by functional ambiguity. In subjunctive (imperative) sentences, native intuition accepts such forms, even if very reluctantly, for want of a better solution (whereas ${ }^{*}$ poroljon is never accepted in this role). The reason for that reluctance is twofold. On the one hand, there are semantic misgivings: because of the 'middle voice' character of verbs of the csuklik type, their imperative form is "superfluous". On the other hand, morphophonological objections also arise: in an intransitive paradigm, a stem alternant with an inserted vowel seems to be out of place.

3.4. Given that stems including an inserted vowel are inappropriate to occur in an intransitive paradigm, while stems with a consonant cluster yield illformed syllable codas, the question now arises why it is not possible to use, in the imperative, stem alternants in which vowel insertion takes place after, rather than within, the cluster, as in conditional froms (cf. porlik porlana $-{ }^{*}$ porolna $-{ }^{*}$ poroljon, but porol $-{ }^{*}$ porlana - porolna - poroljon). Why is *porlajon 'let it powder away' or *csuklajon 'let him hiccough' not possible if porlana 'it would powder away' or csuklana 'he would hiccough' is fine? The answer is this: such forms are excluded by a more general regularity, even in phonotactically similar (CC-final) non-ik verbs. That is, although the conditional of such verbs involves a low vowel inserted between stem and mood marker (e.g., csengene 'it would ring', ajánlana 'he would recommend', áldana 'he would bless'), their imperative forms have none: csengjen 'let it ring' rather than *csengejen, ajánlja 'let him recommend it' rather than *ajánlaja, áldja 'let him bless it' rather than *áldaja.

Nevertheless, the group of verbs we are investigating includes items that, although they are (pairs of) intransitive verbs without a transitive counterpart, their imperatives count as well-formed, against all odds (Table 3). Some of these verbs have a vowel-insertion counterpart, either as a free variant, or else as an unergative counterpart of an unaccusative verb. Variants are listed in the table with a tilde between them; middle/active pairs are linked by a dash.

Further pairs of verbs that presumably belong here are bogárzik bogároz ${ }^{3}$ '[animal be disturbed] by insects' and rögzik4 '?become fixed' rögö $z^{5}$ '?stabilize'. However, none of these except the first member of the first pair are part of the word stock of present-day Hungarian, and even bogárzik occurs rarely (if at all), therefore native intuition is rather vague concerning their conditional or imperative forms, and no historical data are available in the inflected forms required. Indeed, even the intransitive character of rögöz is not unequivocally demonstrated in TESz. In varieties of Hungarian where feslik 'come unstitched' has a variant fesel and hámlik 'be peeling' has a variant hámol (Károly 1957 : 278), they belong in Table 3 , rather than in Table 2. In the varieties of Hungarian in which viszonyul

\footnotetext{
3 bogároz: TESz 1 : 321.

4 rögzik: TESz 3 : 455; SzmSz 192.

5 rögöz: TESz $3: 455$.
} 
Table 3

\begin{tabular}{|c|c|c|c|}
\hline intransitive, indicative & $\begin{array}{l}\text { intransitive, } \\
\text { cond.1 }\end{array}$ & $\begin{array}{l}\text { intransitive, } \\
\text { cond.2 }\end{array}$ & $\begin{array}{l}\text { intransitive, } \\
\text { imperative }\end{array}$ \\
\hline $\begin{array}{l}\text { ködlik 'appear through mist' - } \\
\text { ködöl 'behave misleadingly' }\end{array}$ & ködlene & ködölne & ködöljön \\
\hline döglik 'lie about' & döglene & dögölne & dögöljön \\
\hline hajlik 'bend' - hajol 'bow' & hajlana & hajolna & hajoljon \\
\hline zajlik 1 'take place' & zajlana & $*_{\text {zajolna }}$ & zajoljon \\
\hline zajlik 2 'drift' (of ice) & zajlana & zajolna & zajoljon \\
\hline bicsaklik 'get sprained' & bicsaklana & bicsakolna & bicsakoljon \\
\hline haldoklik haldokol 'be dying' & haldoklana & haldokolna & haldokoljon \\
\hline fuldoklik fuldokol 'be drowning' & fuldoklana & fuldokolna & fuldokoljon \\
\hline tündöklik tündököl 'be glittering' & tündöklene & tündökölne & tündököljön \\
\hline omlik omol 'crumble' & omlana & omolna & omoljon \\
\hline bomlik bomol 'disintegrate' & bomlana & bomolna & bomoljon \\
\hline romlik $\sim$ romol $\dagger^{6}$ 'deteriorate' & romlana & romolna & romoljon \\
\hline$\ddot{o m l i k} \sim \ddot{o m o ̈ l} \dagger^{+}$'flow' & ömlene & ömölne & ömöljön \\
\hline áramlik áramol $\dagger^{8}$ 'stream' & áramlana & áramolna & áramoljon \\
\hline csuszamlik 'be sliding' & csuszamlana & csuszamolna & csuszamoljon \\
\hline iramlik 'scurry' & iramlana & iramolna & iramoljon \\
\hline örvénylik 'whirl' & örvénylene & örvényelne & örvényeljen \\
\hline $\begin{array}{l}\text { oszlik 'get dispersed' - } \\
\text { oszol 'break up' }\end{array}$ & oszlana & oszolna & oszoljon \\
\hline feslik 'come unstithed' & feslene & ${ }^{*}$ feselne & feseljen \\
\hline kotlik kotol 'brood' & kotlana & kotolna & kotoljon \\
\hline lélegzik (be)lélegez 'breathe (in)' & lélegzene & lélegezne & lélegezzen \\
\hline (el)hangzik 'be heard' & (el)hangzana & (el)hangozna & (el)hangozzon \\
\hline hullámzik 'be waving' & hullámzana & ?hullámozna & hullámozzon \\
\hline fogamzik 'be conceived' & fogamzana & *fogamozna & $\begin{array}{l}\text { *fogamozzon } \\
\text { fogamzzon }\end{array}$ \\
\hline nemz 'beget' & nemzene & *neme zne & $\begin{array}{l}\text { *nemezzen } \\
\text { nemzzen }\end{array}$ \\
\hline (ki)rajzik 'hive off' & (ki)rajzana & *(ki)rajozna & $\begin{array}{l}\text { *(ki)rajozzon } \\
(\text { ki)rajzzon }\end{array}$ \\
\hline elfajzik 'degenerate' & $(e l) f a j z a n a$ & *(el)fajozna & $\begin{array}{c}\text { *el)fajozzon } \\
(\text { el)fajzzon }\end{array}$ \\
\hline
\end{tabular}

6 romol: TESz $3: 438-439$.

7 ömöl: TESz $3: 31$.

8 áramol: TESz 1 : 170. 
and viszonylik turn out to be the stem alternants of each other, the illformed *viszonyoljon imperative form of viszonylik will be replaced by viszonyuljon, i. e. the imperative form of viszonyul. This is because the formative $-u l$ with its VC structure licences the regular form (see also point 3.1, above). Accordingly, this will be listed in Table 3. Nevertheless, in other cases, that is to say when viszonylik and viszonyul are not steem alternants of the same verb (see also (meg)hasonlik 'be at variance with' vs. hasonul 'assimilate') viszonyuljon can not be an acceptable imperative of viszonylik (and, similarly, (meg)hasonuljon is not the imperative of (meg)hasonlik).

The data in Table 3 can be divided into two groups:

(a) The last four verbs (fogamzik 'be conceived', nemz 'beget', kirajzik 'hive off', (el)fajzik 'degenerate') - with their stem final consonant clusters ending in $z-$ differ from all the rest in that their imperative forms do exist even though their conditionals with vowel insertion are ill-formed. However, their imperatives do not involve vowel insertion as for all the other verbs in the table: in accordance with their stem alternants used in the conditional, their imperatives also involve the cluster-final stem alternant: (el)fajzzon, (ki)rajzzon, fogamzzon. Both [ $j z]$ and [mz] are clusters that occur in Hungarian in word final clusters undivided by a morpheme boundary, cf. rajz 'drawing', nemz 'beget' etc. Nemz is a unique instance of the investigated verb group in that it is transitive without having a medial not an -ik form counterpart. In all other respects nemz behaves like fogamzik.

(b) The rest of the forms have two well-formed conditional forms, and a well-formed imperative. This larger group includes another verb with $[\mathrm{mz}]$ : hullámzik 'be waving' - even if the conditional ?hullámozna is of somewhat doubtful acceptability. There is a pair of verbs in this group that requires special attention. The two different verbs zajlik 'take place' and zajlik 'drift' diverge at a single point: 'take place' does not admit a nonepenthetic conditional *zajolna. Group (b) includes verbs involving both zfinal and $l$-final clusters ( $[g z, m z]$, and $[g l, j l, k l, m l, h l, t l]$, respectively). The odd man out here is [sl] in oszlik '(get) disperse(d)' with its [+continuant] voiceless obstruent [s] in the stem. Since foszlik 'fray' behaves differently, despite its similar segmental make-up (oszlik - oszlana - oszolna - oszoljon vs. foszlik - foszlana - ${ }^{*}$ foszolna - ${ }^{*}$ foszoljon, cf. Table 2), we can assume that the paradigm of middle-voice oszlik has been influenced by that of active oszol 'break up' - ?oszlana - oszolna - oszoljon. If oszlana is accepted as a well-formed conditional of oszol, this shows further blending between the two paradigms. Despite the fact that the pre$i k$ cluster of oszlik is unique in the class of Table 3, its behaviour clearly shows that it belongs here. Note that a similar distribution and paradigm blend can be observed with unaccusative hajlik 'bend' and unergative hajol 'bow', similarly kotlik and kotol (both: 'brood', with the semantic bifurcation in view of the set of virtual agents belonging to the two variants), as well as middle-voice ötlik 'occur' and active-transitive (ki)ötöl 'figure out', discussed earlier. A number of verbs in group (b) have two alternative forms: an $i k$-verb with a consonant cluster and a non-ik verb with an inserted vowel, e.g. fuldoklik - fuldokol 'be drowning', tündöklik - tündököl 'be glittering', bomlik - bomol 'disintegrate', ömlik - ömöl 'flow', where the two alternatives do not constitute a middle/active pair. This makes it possi- 
ble for these verbs to have two conditionals and consequently a well-formed imperative. The 'cond.2' forms are based on the non-ik versions, yet due to the paradigm blend involved, native intuition accepts them as forms of the corresponding $i k$-verb, too. This is also what happens in the abovementioned middle/active pairs hajlik - hajol, kotlik - kotol, as well as in the pair oszlik - oszol, containing an atypical consonant cluster.

4. The foregoing analysis suggests that no systematic morphophonological description can be completely realistic without taking things like argument structure - eventually, semantic factors - into consideration.

\section{Address}

Judit Szépe

University of Strasbourg

E-mail: szepe@unistra.fr

Károly Gerstner

Research Institute for Linguistics of the Hungarian Academy of Sciences

E-mail: gerstner.karoly@nytud.mta.hu
Tamás Szende

Pázmány Péter Catholic University, Piliscsaba, Hungary

\section{Abbreviations}

ÉKsz. - Magyar értelmező kéziszótár, Budapest, 1972; MRSz — L. E 1 e k f i, Magyar ragozási szótár, Budapest 1994; SzmSz - F. P a p p, A magyar nyelv szóvégmutató szótára, Budapest 1967.

2 sg -2 nd person singular, $3 \mathrm{pl}-3$ rd person plural.

\section{R E F E R E N C E S}

D re s s le r, W. U., S i p tá r, P. 1989, Towards a Natural Phonology of Hungarian. - Acta Linguistica Hungarica 39, 29-51.

E 1 e k f i, L. 1988, Magyar szavak ragozási paradigmái és a ragozási szótár. Műhelymunkák a nyelvészet és társtudományai köréből IV, Budapest, $41-$ 70 .

- - 1992, A magyar hangkapcsolódások fonetikai és fonológiai szabályai, Budapest.

- - 1994, Magyar ragozási szótár, Budapest.

G r é t s y, L. 1985, Tó- és kötőhangzóváltakozások. - Nyelvművelő kézikönyv 2, Budapest, 1047-1088.

H o r g e r, A. 1911, Egy ismeretlen magyar hangtörvény, Budapest (Nyelvészeti Füzetek 65).

K á r o 1 y, S. 1957, A csuklik-féle ikes igék ragozása, képzése. - Nyr. 81, 275281.

L e n g y e 1, K. 2000, Az ig. - Magyar grammatika, Budapest, 81-103.

L o t z, J. 1960, The Imperative in Hungarian (Spoken and Written). - American Studies in Uralic Linguistics, Bloomington, Indiana, 83-92. [Reprinted in:] L o tz, J. 1972, Script, Grammar, and the Hungarian Writing System, Budapest-Washington, $41-47$.

P u s z t a i, F. 2003, Magyar értelmező kéziszótár, Budapest.

R e b r u s, P. 2000, Morfofonológiai jelenségek. - Strukturális magyar nyelvtan 3. Morfológia, Budapest, 763-947.

Rebrus, P. Polgá rd i, K. 1997, Two Default Vowels in Hungarian? Phonology in Progress - Progress in Phonology, The Hague, 257-275.

S i p tá r, P. 1994, A mássalhangzók. - Strukturális magyar nyelvtan 2. Fonológia, Budapest, 183-272.

- - 1995, A magyar mássalhangzók fonológiája. - Linguistica. Series A: Studia et Dissertationes 18, Budapest. 
S i p tá r, P., Törke n c z y, M. 2000, The Phonology of Hungarian, Oxford. S z é p e, Gy. 1969, Az alsóbb nyelvi szintek leírása. - Általános Nyelvészeti Tanulmányok 6, 359-466.

S z i g e t vá ri, P. 2001, Szótagtalan fonológia. - Szabálytalan fonológia, Budapest, $37-76$.

Törke n c z y, M. 1994, A szótag. - Strukturális magyar nyelvtan 2. Fonológia, Budapest, $273-392$.

ЮДИТ СЕПЕ (Страсбург-Будапешт),

КАРОЙ ГЕРШТНЕР, ТАМАШ СЕНДЕ (Будапешт)

\section{ВЕНГЕРСКИЕ ДЕФЕКТНЫЕ ГЛАГОЛЫ И МАРКИРОВАНИЕ НАКЛОНЕНИЙ}

В статье рассматриваются нерегулярные спрягаемые формы венгерских дефектных (недостаточных) глаголов (например, hajlik 'изгибаться, склоняться'). Параллельные нормативные варианты (например, hajolna и hajlona 'изгибаясь, склоняясь') свидетельствуют о том, что выбор того или иного варианта не зависит прежде всего от слоговой структуры, а скорее от того, является ли аргумент агенсом или это пациенс. 